\title{
Faktor-faktor yang mempengaruhi ekspor pala Indonesia ke Vietnam
}

\author{
Vivi Novidayanti*; Siti Hodijah; Candra Mustika
}

Prodi Ekonomi Pembangunan, Fak. Ekonomi dan Bisnis, Universitas Jambi

*E-mail korespondensi: vivinvdayanti1206@gmail.com

\begin{abstract}
The purpose of this study was to analyze the factors that influence Indonesia's nutmeg exports to Vietnam, with the variables of exchange rates, international prices, and Vietnam's gross domestic product. The data analysis method used is descriptive and quantitative methods, the data analysis tool used is the OLS (Ordinary Least Square) method. Includes annual data for 38 years, with secondary data sourced from the Directorate General of Plantations, Bank Indonesia, and the World Bank as research objects. The data analysis technique is multiple linear regression, partial hypothesis testing using the t-test, and simultaneously using the F-test with a significant level of $5 \%$. Based on the results, it can be concluded that partially the exchange rate (NT) has a positive and significant effect on export volume (VE); international price (HI) has a negative and significant effect on export volume (VE), and Vietnam's gross domestic product (GDP) has a positive and significant impact on the export volume (VE) of Indonesian nutmeg.
\end{abstract}

Keywords: Export volume, Exchange rate, International price, Gross domestic product.

\begin{abstract}
Abstrak
Tujuan dari penelitian ini adalah untuk menganalisis faktor-faktor yang mempengaruhi ekspor pala Indonesia ke Vietnam, dengan variabel nilai tukar,harga internasional, dan gross domestic product Vietnam. Metode analisis data yang digunakan adalah metode deskriptif dan kuantitatif, alat analisis data yang digunakan adalah metode OLS (Ordinary Least Square). Meliputi data tahunan selama 38 tahun, dengan data sekunder yang bersumber dari Direktorat Jenderal Perkebunan, Bank Indonesia, dan World Bank sebagai objek penelitian. Teknik analsis data adalah regresi linier berganda, pengujian hipotesis secara parsial menggunakan Uji-t dan secara simultan menggunakan Uji-F dengan tingkat signifikan 5\%. Berdasarkan hasil, dapat disimpulkan bahwa secara parsial nilai tukar (NT) memiliki pengaruh positif dan signifikan terhadap volume eskpor (VE); harga internasional(HI) memiliki pengaruh negatif dan signifikan terhadap volume eskpor (VE); dan gross domestic product Vietnam (GDP) memiliki pengaruh positif dan signifikan terhadap volume ekspor (VE) pala Indonesia.
\end{abstract}

Kata kunci: Volume ekspor, Nilai tukar, Harga internasional, Gross domestic product.

\section{PENDAHULUAN}

Dari waktu ke waktu terjadi perubahan akan tatanan kehidupan manusia, diikuti dengan semakin meningkatnya ilmu pengetahuan dan pesatnya teknologi. Sejalan dengan proses tersebut maka semakin banyak dan bervariasi pula tuntutan pemenuhan kebutuhan manusia yang meliputi barang dan jasa, sayangnya kebutuhan manusia itu tidak terpenuhi dengan jumlah apa yang di produksi negara bersangkutan. Hal ini dapat 
terjadi dikarenakan keterbatasan yang dimiliki negara tersebut baik dari sisi sumber daya alam ataupun sumber daya manusianya. Sumber daya alam di setiap negara yang memiliki perbedaan masing-masing hal inilah yang membedakan corak perekonomian negara-negara di dunia. Dan setiap negara pasti membutuhkan hasil produksi negaranegara lain, pada akhirnya akan terjadi aktivitas perdagangan internasional (Tan, 2016).

Perdagangan internasional diartikan sebagai suatu aktivitas yang dilakukan oleh penduduk negara satu dengan penduduk negara lain atas dasar kesepakatan bersama. Aktivitas perdagangan internasional terdiri dari dua jenis yaitu impor dan ekspor. Impor adalah aktivitas yang berakibat pada mengalirnya devisa suatu negara ke luar negeri karena terjadinya transaksi perdagangan internasional, sedangkan ekspor adalah aktivitas menjual barang dan jasa dari daerah yang meliputi wilayah darat, perairan, dan udara suatu negara sesuai peraturan dan perundangan yang berlaku (Purnawati, Astuti, Fatmawati, 2013). Ekspor memiliki peranan yang sangat kuat dalam perekonomian suatu negara, seperti Indonesia yang dapat dikatakan sangat bergangtung terhadap aktivitas ekspor. Umumnya, Indonesia melakukan ekspor barang-barang yang terdiri atas dua jenis, yaitu minyak bumi dan gas alam (migas) dan selain minyak bumi dan gas alam (non migas).

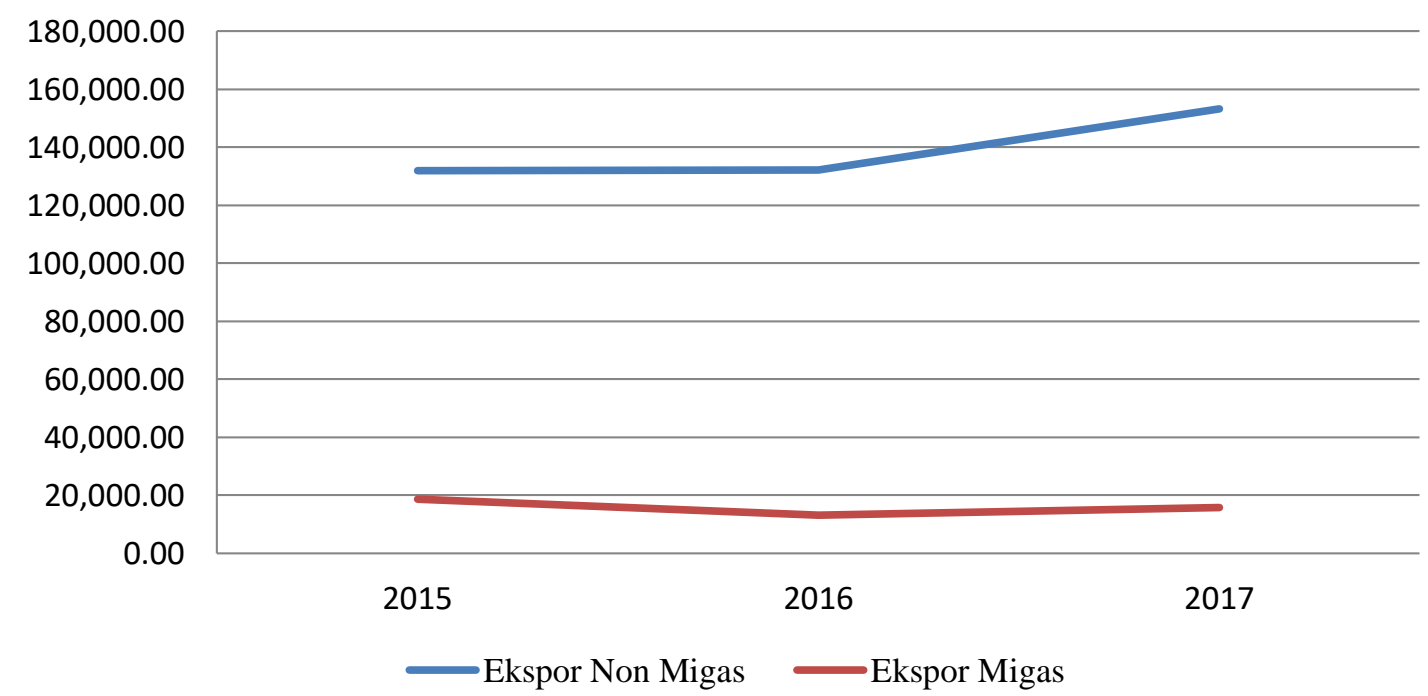

Sumber : BPS. Data diolah, 2019

Gambar 1. Ekspor non migas dan migas Indonesia

Indonesia memiliki ciri khas sebagai negara agraris yang artinya sektor yang memainkan peranan utama dalam negera ini adalah sektor pertanian. Oleh sebab itu dengan memanfaatkan potensi yang tersedia sektor pertanian menjadi sektor pemberi kontribusi yang besar untuk pembangunan perekonomian nasional. Salah satu sumber kekayaan melimpah yang dimiliki Indonesia yang dikenal sebagai negara tropis adalah sektor pertanian, dimana hasil pertanian yang berupa produknya sangat berkontribusi terhadap pendapatan nasional yang cukup besar setiap tahunnya, dan hasil dari sektor ini sangat berperan penting dalam pertumbuhan ekonomi di Indonesia (Arham, 2009).

Di dalam sektor pertanian terbagi atas beberapa sub sektor yaitu subsektor tanaman pangan, perikanan, kehutanan, peternakan dan perkebunan. Fokus utama dalam penelitian ini adalah sektor perkebunan, pemerintah Indonesia mengutamakan pengembangan subsektor perkebunan karena memiliki daya tarik tinggi untuk diekspor kenegara maju, sektor perkebunan ini memiliki peranan bagi pembangunan nasional.

Pala (Myristica Fragrans) adalah tanaman rempah asli Maluku dan telah 
diperdagangkan dan dibudayakan secara turun menurun dan pala adalah salah satu komoditas subsektor perkebunan. Buah pala dikenal sebagai tanaman rempah yang memiliki nilai ekonomis dan multiguna. Fungsi utama dari pala adalah sebagai rempah, baik untuk keperluan sehari-hari atau untuk industri makanan dan minuman. Daging buah pala yang muda dimanfaatkan untuk diolah menjadi makananan dan minuman seperti manisan, permen, sirup, dan jus pala. Minyak pala yang diperoleh dari penyulingan biji pala muda sebagian langsung diekspor dan sebagian lagi dimanfaatkan menjadi bahan baku industri obat-obatan, mentega pala (trimisin), parfum, sabun, dan komestik didalam negeri. Pala dipilih sebagai tujuan penelitian ekspor dikarenakan berdasarkan data pada policy brief 2017 Indonesia adalah negara pernghasil terbesar pala dengan pasokan 66-77 persen dari kebutuhan pala dunia, diikuti oleh Srilangka 813 persen, dan Grenada 3-26 persen.

Berdasarkan Pusat Data dan Informasi pertanian 2016 negara Vietnam, Belanda, Amerika Serikat, dan India adalah negara tujuan terbesar ekspor pala Indonesia pada tahun 2015. Volume ekspor pala Indonesia ke Vietnam sebesar 7.736 ton, Belanda sebesar 1.427 ton, Amerika Serikat sebesar 1.420, India sebesar 1.389 ton dan sisanya 5.054 ton diekspor ke negara lainnya. Adapun tujuan ekspor biji pala Indonesia adalah ke negara Vietnam karena berdasarkan pusat data dan sistem informasi pertanian 2015, negara Vietnam menduduki posisi pertama sebagai negara tujuan ekpor pala Indonesia.

Sebagai penghasil devisa nonmigas pala saat ini sangat di pertimbangkan kedudukannya. Peranan pala dalam perekonomian Indonesia memiliki arti penting baik dalam aspek ekonomi dan sosial. Ada beberapa faktor yang dibahas dalam penelitian ini, diantaranya adalah nilai tukar, harga internasional, dan gross domestic product Vietnam.

Nilai tukar adalah variabel yang sangat berpengaruh terhadap ekspor pala karena nilai tukar merupakan alat transaksi yang digunakan dalam perdagangan internasional. Secara mendasar, semakin rendah mata uang rupiah (terjadi depresiasi rupiah), membuat harga komoditi juga semakin rendah dan menberdampak pada harga komoditi Indonesia menjadi lebih murah dibandingkan dengan negara lain. Artinya, semakin rendah mata uang suatu negara akan membuat ekspor dapat lebih bersaing di dunia karena harga yang di tawarkan jauh lebih murah dibandingkan dengan negara lain dan dimungkinkan ekspor Indonesia menjadi naik. Tetapi jika kondisi nilai tukar yang terlalu rendah dan terjadi terus menerus juga akan berakibat buruk bagi perekonomian suatu negara.

Harga internasional adalah faktor yang sangat penting dalam menentukan ekspor suatu komoditi. Tinggi rendahnya harga internasional pala Indonesia akan berpengaruh terhadap permintaan ekspor pala Indonesiaa ke Vietnam. Semakin tinggi harga internasional pala Indonesia maka semakin rendah permintaan komoditi pala asal Indonesia, hal ini sesuai dengan hukum permintaan, bila harga suatu komoditi naik maka permintaan komoditi tersebut akan turun, sebaliknya bila harga komoditi tersebut turun maka permintaannya akan naik dengan asumsi cateris paribus (semua faktor yang mempengaruhi permintaan selain harga dianggap konstan).

Gross domestic product adalah variabel yang menggambarkan keadaan perekonomian suatu negara. Apabila gross domestic product suatu negara semakin besar berarti menunjukkan keadaan perekonomian suatu negara tersebut semakin baik karena pendapatan negara tersebut yang semakin meningkat. Oleh karena itu apabila terjadi peningkatan gross domestic product negara Vietnam, maka akan semakin meningkatnya kemampuan negara Vietnam dalam kegiatan perdagangan internasional, dan akhirnya berdampak pada meningkatnya permintaan pala Indonesia ke Vietnam. 


\section{METODE}

\section{Jenis dan sumber data}

Jenis data dalam penelitian ini merupakan data sekunder, Data sekunder merupakan data yang diterbitkan digunakan oleh organisasi yang bukan pengolahnya (Soeratno, 2008). Penelitian ini terdiri dari beberapa variable yakni nilai tukar, harga internasional, dan gross domestic product Vietnam sebagai variable bebas (independent) serta volume eskpor sebagai variabel terikat (dependent). Adapun data yang digunakan adalah data deret waktu atau (time series) meliputi data tahunan selama 38 tahun yaitu dari tahun 1980 sampai dengan tahun 2017 sesuai dengan ketersediaan data. Sumber data yang digunakan dalam penelitian ini berasal dari : Direktorat jenderal perkebunan, Bank Indonesia, dan world bank.

\section{Analisis deskriptif}

Analisis deskriptif adalah analisis yang dilakukan untuk menilai karakteristik dari sebuah data dengan cara memberikan pengambaran. Tujuan dari analisis deskriptif ini adalah untuk menyajikan gambaran secara sistematis dan akurat mengenai hubungan antar fenomena yang diteliti. Analisis deskriptif dalam penelitian ini digunakan untuk menjawab tujuan pertama yaitu mengetahui perkembangan ekspor pala Indoensia dilihat dari sisi voume ekspor, nilai tukar, harga internasional dan gross domestic product Vietnam. Analisis yang dilakukan dengan menjelaskan voume ekspor, nilai tukar, harga internasional dan gross domestic product Vietnam tahun 1980-2017. Untuk menjawab tujuan pertama digunakan dengan rumus model analisis perkembangan sebagai berikut:

Dimana :

$$
G_{x}=\frac{X_{t}-X_{t-1}}{X_{t-1}} \times 100 \% \ldots
$$

$G_{x} \quad=$ Persentase perkembangan pada tahun $\mathrm{x}$

$\mathrm{Xt} \quad=$ Data $\mathrm{x}$ tahun terntentu.

$X_{t-1}=$ Data $\mathrm{x}$ tahun sebelumnya

\section{Analisis kuantitatif}

Untuk menganalisis pengaruh nilai tukar, harga internasional, dan gross domestic product Vietnam terhadap ekspor pala Indonesia dengan menggunakan analisis regresi linier berganda. Berikut model estimasi ekspor pala Indonesia yang digunakan dalam penelitian ini:

$$
V E_{t} \quad=\beta_{0}+\beta_{1} N T_{t}+\beta_{2} H I_{t}+\beta_{3} G D P_{t}+e_{t}
$$

Dimana:

VE $\quad=$ Volume ekspor pala (Ton)

$\beta_{0} \quad=$ Konstanta

$\beta_{1} \beta_{2} \beta_{3} \quad=$ Parameter yang diduga $(\mathrm{n}=1,2,3)$

NT $\quad=$ Nilai tukar $(\mathrm{Rp})$

HI $\quad=$ Harga Internasional (US\$)

GDP $\quad=$ GDP Vietnam (US\$ milliar)

$\mathrm{t} \quad=$ Periode

$\mathrm{e} \quad=$ Residual 


\section{Uji F statistik (uji bersama-sama)}

Pada penelitian ini, uji $\mathrm{F}$ dilakukan dengan membandingkan $\mathrm{F}$ hitung dengan $\mathrm{F}$ tabel. Jika F hitung lebih besar dari F tabel atau nilai signifikansi nya lebih kecil dari tingkat alpha 0,05 hal ini berarti variabel independent secara keseluruhan berpengaruh terhadap volume permintaan ekspor pala Indonesia (variabel dependent). Sebaliknya jika $\mathrm{F}$ hitung lebih kecil dari $\mathrm{F}$ tabel, atau nilai signifikannya lebih besar dari tingkat alpha 0.05 hal ini berarti variabel independen secara keseluruhan tidak berpengaruh terhadap variabel dependen.

\section{Uji t (uji parsial)}

Uji hipotesis parsial maksudnya bahwa uji dilakukan terhadap masing-masing variabel bebas terhadap variabel terikatnya. Signifakansi dari parameter dapat ditunjukkan dari nilai t-statistik maupun nilai probabilitas. Cara yang dapat digunakan adalah menggunakan nilai probabilitas yang tertera dari hasil estimasi. Jika digunakan nilai ini, maka perlu diandingkan dengan level kepercayaan meliputi $1 \%$, 5\%, dan $10 \%$. Pemilihan nilai tersebut ditentukan oleh peneliti dengan mendasarkan pada nilai karakteristik data, model maupun prosedur estimasi yang dilakukan (Wahyudi, 2016).

\section{Uji koefesien determinasi $\left(\mathbf{R}^{2}\right)$}

Lind dkk (2002) menjelaskan bahwa koefesien determinasi berganda adalah persen variasi dalam model yang mampu dijelaskan oleh variabel bebas. Besarnya nilai koefesien determinasi yang berarti variabel independen mempu menjelaskan variabel dependen. $\mathrm{R}^{2}$ memiliki range antara $0 \leq \mathrm{R}^{2} \leq 1$. Jika $\mathrm{R}^{2}$ memiliki nilai 1 maka garis regresi menjelaskan 100 persen variasi dalam $Y$. Sedangkan jika $R^{2}$ memiliki nilai 0 maka garis regresi tidak menjelaskan variasi dalam Y.

\section{Uji normalitas}

Dalam persamaan regresi, asumsi normalitas mensyaratkan nilai nilai dari variabel $\mathrm{Y}$ berdistribusi normal pada tiap nilai dari $\mathrm{X}$. Keadaan normal diketahui melalui sebaran regresi yang merata disetiap nilai. Uji normalitas bertujuan untuk menguji apakah dalam model regresi, variabel pengganggu dan residual memiliki distribusi normal (Ghozali, 2011).

\section{Uji multikolinearitas}

Uji multikolinearitas bertujuan untuk menguji apakah dalam model regresi ditemukan adanya korelasi antara variabel dependen (Ghozali, 2011). Multikolinearitas menyebabkan pendugaan koefesien regresi tidak nyata, walaupun nilai koefesien determinasi tinggi, konsekuensi dari multikolinearitas sendiri berbeda-beda tergantung dari eratnya hubungan linier yang terjadi pada variabel penjelas. Uji multikolinearitas dapat dilakukan dengan memperhatikan nilai Variance Inflation Factor atau VIF.

\section{Uji heterokedastisitas}

Uji heteroskedastisitas adalah uji yang bertujuan menguji apakah dalam model regresi terjadi ketidaksamaan varians dalam suatu pengamatan terhadap pengamatan lainnya (Ghozali, 2011). Model regresi yang baik adalah model yang varians dari satu pengamatan ke pengamatan lain tetap. Adapun konsekuensi dari adanya heteroskedastisitas adalah estimator $\beta_{1}$ yang didapatkan akan mempunyai varian yang tidak minimum. Meski estimator metode OLS masih linier dan tidak bias, varian yang tidak minimum akan membuat perhitungan standar error metode OLS tidak dapat dipercaya kebenarannya. 


\section{Uji autokorelasi}

Uji autokorelasi adalah uji yang bertujuan menguji apakah dalam model regresi linier ada korelasi antara kesalahan pengganggu pada periode $\mathrm{t}$ dengan kesalahan pengganggu pada periode t-1 (Ghozali, 2011). Konsekuensi adanya masalah autokorelasi adalah estimator OLS tidak mempunyai varian yang minimum meskipun estimator OLS masih linier dan tidak bias. Beberapa cara yang dapat digunakan untuk mendeteksi masalah autokorelasi adalah metode Durbin-Watson, dan Breusch-Godfrey.

\section{HASIL DAN PEMBAHASAN}

\section{Perkembangan ekspor pala}

Ada beberapa faktor yang dibahas dalam penelitian ini, diantaranya adalah nilai tukar, harga internasional, dan gross domestic product Vietnam. Di Indonesia perkembangan nilai tukar sejak tahun 1980-2017 mengalami fluktuasi dan cenderung mengalami depresiasi, dengan rata-rata melemahnya nilai tukar rupiah terhadap US\$ 12,2 persen pertahun. Sedangkan perkembangan harga internasional pala sejak tahun 1980-2017 mengalami fluktuasi dan cenderung meningkat, dengan rata-rata peningkatan berada pada angka 14,4 persen. Dan gross domestic product Vietnam sejak tahun 1980-2017 mengalami fluktuasi dan cenderung meningkat, dengan rata-rata peningkatan berada pada angka 12,4 persen.

\section{Volume ekspor pala Indonesia}

Dari sisi volume ekspor pala selama kurun waktu 1980 - 2017 mengalami fluktuasi dan cenderung meningkat, hal ini terlihat pada tahun 1977 volume ekspor pala Indonesia berada pada angkat 6.785 ton. Pada tahun 1990 volume ekspor pala Indonesia mencapai angka 7.441 ton. Dan pada tahun 2007 tembus pada angka 16.702 ton. hingga pada lima tahun terakhir 2013-2017 volume ekspor pala Indonesia terus mengalami peningkatan, khususnya pada tahun 2015 yang merupakan tahun dimana volume ekspor pala meningkat cukup pesat dikarenakan adanya Undang-Undang Nomor 39 Tahun 2014 tentang perkebunan dimana didalamnya membahas pengaturan penyelenggaraan perkebunan. Hanya saja pada tahun 2016 terjadi penurunan volume ekspor pala Indonesia yang cukup signifikan hal ini disebabkan oleh penolakan berbagai negara dunia terhadap komoditas pala Indonesia dengan alasan komoditas pala Indonesia tercemar mikrotoksin melebihi ambang batas, namun berkat perbaikan mutu yang dilakukan maka terjadi peningkatan yang signifikan dalam ekspor pala Indonesia pada tahun 2017 terbukti volume ekspor pala Indonesia pada tahun 2017 menduduki angka 19.939 ton.

\section{Nilai tukar}

Dari sisi nilai tukar rupiah terhadap US US\$ selama kurun waktu 1980 - 2017 mengalami fluktuasi dan cenderung mengalami depresiasi (melemahnya nilai tukar rupiah terhadap US\$), pada tahun 1998 terjadi depresiasi nilai tukar yang sangat signifikan, yang pada tahun 1997 sebesar Rp.2.909 persatu US\$ menjadi Rp.10.014 persatu US\$, perubahan ini terjadi karena rezim yang dulunya menerapkan sistem nilai tukar tetap, bergerak ke arah nilai tukar yang mengambang terkendali, dan sejak tahun 1997 saat krisis moneter menghantam Indonesia pemerintah menetapkan sistem nilai tukar mengambang bebas. Bersamaan dengan pergantian sistem nilai tukar, Indonesia 
mengalami krisis moneter yang meenyebabkan nilai tukar rupiah terhadap US\$ terdepresiasi dan memiliki tingkat velositas yang cukup tinggi. Hingga lima tahun terakhir 2013-2017 nilai tukar rupiah terhadap US\$ terus terdepresiasi, dan pada tahun 2017 nilai tukar cenderung lebih stabil berada pada nilai Rp. 13.384.

\section{Harga internasional}

Dari sisi harga internasional pala Indonesia, selama kurun waktu 1980-2017 harga internasional pala mengalami fluktuasi dan meningkat, untuk tahun 1983 harga internasional pala Indonesia berada pada angka 0,88874 US\$ dimana merupakan harga internasional pala terendah selama periode 1980-2017 hal ini mengindikasikan pada tahun 1983 nilai tukar petani terendah dicapai yang dikarenakan adanya kenaikan harga produk produk pertanian yang relatif lambat dibanding produk non pertanian, Untuk lima tahun terakhir yaitu tahun 2013-2017 harga internasional pala Indonesia berfluktuasi dan cenderung terus menurun terbukti pada tahun 2013 harag internasional pala berada pada angka 9,02981 US\$ hingga tahun 2017 hanya mencapai harga 5,47756 US\$.

\section{Gross Domestic Product Vietnam}

Dari sisi Gross Domestic Product (GDP) Vietnam secara keseluruhan mengalami fluktuasi yang cenderung meningkat. Pada tahun1987, gross domestic product Vietnam mencapai US\$42,045 milliar hal ini karena pada tahun sebelumnya 1986 Kongres Partai Keenam memperkenalkan reformasi ekonomi luas yang disebut Doi Moi (Renovasi). Revolusi ini merubah sistem ekonomi yang semula terpusat terencana menjadi sistem ekonomi campuran. Kepemilikan swasta digenjot dalam berbagai bidang seperti industri, perdagangan, dan pertanian yang mendorong peningkatan sektor-sektor perekonomian Vietnam yang berdampak pada peningakatan gross domestic product Vietnam pada tahun 1987. Sedangkan, untuk gross domestic product Vietnam terendah selama periode 1980-2017 yang berada pada tahun 1989 yaitu US\$6.293 milliar hal ini terjadi karena peranan pertanian terhadap pemasukan ekonomi berkurang sehingga berdampak terhadap gross domestic product Vietnam. Pertumbuhan ekonomi Vietnam yang terus meningkat dari tahun ke tahun sejak tahun 1990 hingga 2005 membuat Vietnam dikenal sebagai negara dengan pertumbuhan ekonomi tercepat kedua didunia.

\section{Analisis faktor-faktor yang mempengaruhi ekspor pala Indonesia ke Vietnam}

Dari hasil estimasi data dengan menggunakan regresi linier berganda dengan alat analisis Eviews 8.0 dengan menggunakan moteode OLS (Ordinary Least Square). Pengujian ini dilakukan untuk mengetahui tujuan yang telah dituliskan sebelumnya yaitu mengalisis pengaruh nilai tukar, harga internasional, dan gross domestic product Vietnam terhadap volume ekspor pala Indonesia ke Vietnam selama periode 1980 2017. Setelah dilakukan serangkaian empat pengujian asumsi klasik yang terdiri dari uji normalitas, uji multikolinearitas, uji hereroskedastisitas, dan uji autokorelasi, semua dinyatakan lolos. Dari hasil estimasi data menunjukkan persamaan regresi antara volume ekspor (VE), nilai tukar (NT), harga internasional (HI), dan gross domestic bruto (GDP) pada tahun 1980-2017 sebagai berikut :

$$
V E_{t}=7462.776+0.471215 N T_{t}-478.5302 H I_{t}+0.033625 G D P_{t}
$$


Tabel 1. Hasil regresi linear berganda

\begin{tabular}{ccccc}
\hline Variable & Coefficient & Std. Error & t-Statistic & Prob. \\
\hline C & 7462.776 & 702.5349 & 10.62264 & 0.0000 \\
NT & 0.471215 & 0.111508 & 4.225853 & 0.0002 \\
HI & -478.5302 & 199.6915 & -2.396347 & 0.0222 \\
GDP & 0.033625 & 0.009123 & 3.685 .935 & 0.0008 \\
\hline R-squared & 0.728083 & Mean dependent var & 10566.68 \\
F-statistic & 30.34601 & Durbin-Watson stat & 1.489298 \\
Prob(F-statistic) & 0.000000 & & & \\
\hline
\end{tabular}

Sumber: Data diolah, 2019

Dari hasil pengolahan data diperoleh konstanta sebesar 7462,776 artinya jika diasumsikan nilai tukar, harga internasional, dan gross domestic product Vietnam bernilai 0 maka rata-rata volume ekspor pala Indonesia ke Vietnam sebesar 7462,776 ton.

Koefesien regresi untuk variabel nilai tukar (NT) sebesar 0,471215 artinya jika mengasumsikan variabel harga internasional dan gross domestic product Vietnam tetap maka setiap terjadi kenaikan atau depresiasi nilai tukar rupiah sebesar satu rupiah terhadap US\$ maka volume ekspor pala Indonesia ke Vietnam akan meningkat sebesar 0,471215 ton.

Koefesien regresi untuk variabel harga internasional (HI) sebesar 478,5302 artinya jika mengansumsikan variabel nilai tukar dan gross domestic product Vietnam tetap maka setiap terjadi kenaikan harga internasional pala sebesar satu US\$ maka volume ekspor pala Indonesia ke Vietnam akan menurun sebesar 478,5302 ton. Dan sebaliknya ketika terjadi penurunan harga internasional pala sebesar satu US\$ maka volume ekspor pala Indonesia ke Vietnam akan meningkat sebesar 478,5302 ton.

Koefesien regresi untuk variabel gross domestic product Vietnam (GDP) sebesar 0,033625 artinya jika mengansumsikan variabel nilai tukar dan harga internasional tetap maka setiap terjadi kenaikan gross domestic product Vietnam sebesar satu milliar US\$ maka volume ekspor pala Indonesia ke Vietnam akan meningkat sebesar 0,033625 ton.

\section{Uji F (uji bersama-sama)}

Berdasarkan hasil olehan data diperoleh, nilai F-statistik sebesar 30,34601 dengan probabilitas sebesar 0.000000. karena nilai probabilitas lebih kecil dari tingkat keyakinan 5 persen, maka secara simultan variabel nilai tukar (NT), harga internasional(HI), dan gross domestic product Vietnam(GDP) berpengaruh signifikan terhadap variabel volume eskpor (VE) pala Indonesia ke Vietnam.

\section{Uji t (uji parsial)}

Berdasarkan hasil olahan data diperoleh nilai prob. nilai tukar dan gross domestic product Vietnam lebih kecil dari tingkat signifikansi 5 persen dan t statistik 
untuk nilai tukar dan gross domestic product Vietnam bernilai positif. Hal ini menunjukkan bahwa nilai tukar dan gross domestic product Vietnam berpengaruh positif dan signifikan tehadap volume eskpor pala Indonesia ke Vietnam. Sedangkan nilai prob. harga pala internasional lebih kecil dari tingkat signifikansi 5 persen dan $\mathrm{t}$ statistik untuk harga pala intenasional bernilai negatif. hal ini menunjukkan bahwa harga pala internasional berpengaruh negatif dan signifikan terhadap volume eskpor pala Indonesia ke Vietnam.

\section{Uji koefesien determinasi $\mathbf{R}^{2}$}

Berdasarkan hasil olahan data diperoleh nilai $\mathrm{R}^{2}$ sebesar 0,728083 artinya bahwa variabel bebas (nilai tukar, harga internasional dan gross domestic product Vietnam) mempengaruhi variabel tidak bebas (volume ekspor) sebesar 72,80 persen, sedangkan sisanya 27,20 persen dipengaruhi oleh faktor lain yang tidak dimasukkan dalam penelitian. Angka ini menunjukkan kuatnya hubungan antar variabel.

\section{Uji normalitas}

Berdasarkan uji normalitas diketahui bahwa nilai Prob. Jarque-bera hitung sebesar 0,115514 lebih besar dari tingkat $a=5$ persen. Sehingga dapat disimpulkan bahwa residual terdistribusi normal yang artinya asumsi klasik tentang kenormalan telah dipenuhi. Hasil dari uji normalitas dapat dilihat pada gambar :

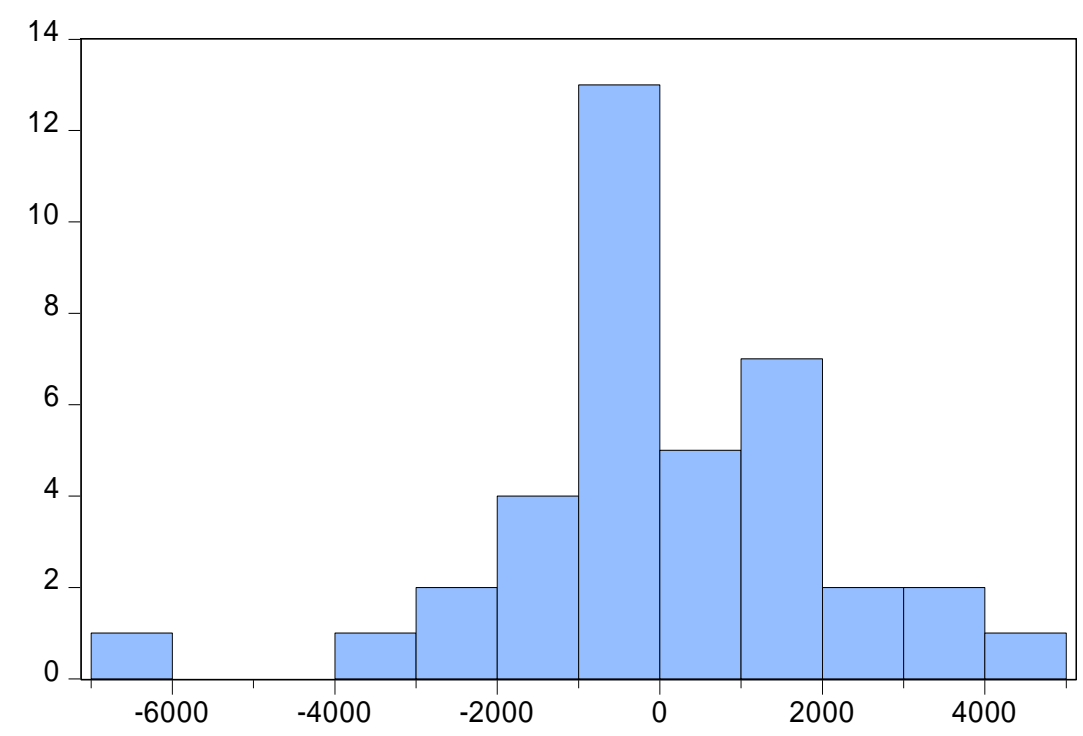

\begin{tabular}{|ll}
\hline \multicolumn{2}{|l|}{ Series: Residuals } \\
Sample 1 38 \\
Observations 38 \\
Mean & $-1.18 \mathrm{e}-12$ \\
Median & -183.2679 \\
Maximum & 4059.704 \\
Minimum & -6285.513 \\
Std. Dev. & 1990.339 \\
Skewness & -0.489952 \\
Kurtosis & 4.328965 \\
& \\
Jarque-Bera & 4.316734 \\
Probability & 0.115514
\end{tabular}

Sumber: Data diolah, 2019

Gambar 2. Uji normalitas

\section{Uji multikolinearitas}

Berdasarkan hasil uji multikolinearitas, dapat dilihat pada tabel kolom Centered VIF. Apabila nilai Centered VIF di bawah 10 maka model tidak bermasalah sehingga model dapat digunakan. Nilai VIF untuk variabel nilai tukar, harga internasional, dan gross domestic product Vietnam tidak ada yang lebih besar dari 10 maka dapat dikatakan tidak terjadi multikolinearitas pada ketiga variabel penjelas tersebut. Hasil uji multikolinearitas dapat dilihat pada tabel 2 dibawah ini:

Tabel 2. Hasil variance inflation factor (VIF) 


\begin{tabular}{cccc}
\hline Variable & $\begin{array}{c}\text { Coefficient } \\
\text { Variance }\end{array}$ & $\begin{array}{c}\text { Uncentered } \\
\text { VIF }\end{array}$ & $\begin{array}{c}\text { Centered } \\
\text { VIF }\end{array}$ \\
\hline C & 493555.3 & 4.350535 & NA \\
NT & 0.012434 & 6.307139 & 2.188235 \\
HI & 39876.71 & 7.593780 & 2.004684 \\
GDP & $8.32 \mathrm{E}-05$ & 5.740044 & 2.814763 \\
\hline
\end{tabular}

Sumber: Data diolah, 2019

\section{Uji heterokedastisitas}

Hasil uji heteroskedastisitas, dapat dilihat bahwa nilai Prob. F hitung sebesar 0,2012 lebih besar dari tingkat $a=5$ persen. Maka melalui uji Breusch-Pagan-Godprey dapat disimpulkan bahwa penelitian ini terbebas dari masalah heteroskedastisitas. Hasil perhitungan terlihat pada tabel 3 sebagai berikut:

Tabel 3. Hasil uji heterokedastisitas

\begin{tabular}{|c|c|c|c|}
\hline F-statistic & 1.627426 & Prob. F & 0.2012 \\
\hline R-squared & 4.771493 & Prob. Chi-Square & 0.1893 \\
\hline Scaled explained SS & 6.358053 & Prob. Chi-Square & 0.0954 \\
\hline
\end{tabular}

Sumber: Data diolah, 2019

\section{Uji autokorelasi}

LM Test Hasil uji autokorelasi, dapat dilihat nilai Prob. F(2,32) sebesar 0,3237 lebih besar dari tingkat $a=5$ persen. Maka dapat disimpulkan bahwa penelitian ini terbebas dari masalah autokorelasi. Hasil perhitungan terlihat pada tabel sebagai berikut:

Tabel 4. Hasil uji autokorelasi

\begin{tabular}{|c|c|c|c|}
\hline \multicolumn{4}{|c|}{ Breusch-Godfrey Serial Correlation LM Test: } \\
\hline F-satistic & 1.168653 & Prob. F(3,34) & 0.3237 \\
\hline Obs*R-square & 2.586621 & Prob. Chi-Squared(3) & 0.2744 \\
\hline
\end{tabular}

Sumber: Data diolah, 2019

\section{Pengaruh nilai tukar terhadap ekspor}

Koefesien regresi untuk variabel nilai tukar adalah sebesar 0,471215. Nilai ini memiliki arti bahwa nilai tukar berpengaruh positif terhadap volume ekspor pala Indonesia ke Vietnam. Dan apabila variabel lain dianggap tetap atau tidak berubah, maka jika terjadi kenaikan atau depresiasi nilai tukar rupiah sebesar 1 rupiah maka akan menyebabkan volume eskpor meningkat sebesar 0,471215 ton. Secara mendasar, semakin rendah mata uang rupiah (terjadi depresiasi rupiah), membuat harga komoditi juga semakin rendah dan berdampak pada harga komoditi Indonesia menjadi lebih murah dibandingkan dengan negara lain. Artinya, semakin rendah mata uang suatu negara akan membuat ekspor dapat lebih bersaing di dunia karena harga yang di tawarkan jauh lebih murah dibandingkan dengan negara lain dan dimungkinkan ekspor Indonesia menjadi naik. Hasil penelitian ini mendukung penelitian Dewi dan Dewi (2015) yang berjudul "Pengaruh Jumlah Produksi, Kusr Dollar Amerika Serikat dan Luas Areal Lahan Terhadap Ekspor Karet Indonesia Tahun 1993-2013" yang beranggapan bahwa nilai tukar berpengaruh positif terhadap volume eskpor.

Pengaruh harga internasional terhadap ekspor 
Koefesien regresi untuk variabel harga internasional adalah sebesar -478,5302. Nilai ini memiliki arti bahwa harga internasionalberpengaruh negatif terhadap volume ekspor pala Indonesia ke Vietnam. Dan apabila variabel lain dianggap tetap atau tidak berubah, maka jika terjadi kenaikan harga pala internasional sebesar 1 US\$ maka akan menyebabkan volume eskpor pala Indonesia ke Vietnam menurun sebesar 478,5302 ton. Harga internasional adalah faktor yang sangat penting dalam menentukan ekspor suatu komoditi. Tinggi rendahnya harga internasional pala Indonesia akan berpengaruh terhadap permintaan ekspor pala Indonesiaa ke Vietnam. Semakin tinggi harga internasional pala Indonesia maka semakin rendah permintaan komoditi pala asal Indonesia, hal ini sesuai dengan hukum permintaan, bila harga suatu komoditi naik maka permintaan komoditi tersebut akan turun, sebaliknya bila harga komoditi tersebut turun maka permintaannya akan naik dengan asumsi cateris paribus (semua faktor yang mempengaruhi permintaan selain harga dianggap konstan). Hal ini juga sesuai dengan penelitian yang dilakukan oleh Mejaya, Fanani, dan Mawardi (2016) dengan judul "Pengaruh Produksi, Harga Internasional, dan Nilai Tukar Terhadap Volume Ekspor" yang beranggapan bahwa harga intenasional internasional berpengaruh negatif terhadap volume ekspor.

\section{Pengaruh Gross Domestic Product Vietnam terhadap ekspor}

Koefesien regresi untuk variabel gross domestic product Vietnam adalah sebesar 0,033625. Nilai ini mempunyai arti bahwa gross domestic product Vietnam berpengaruh positif terhadap volume eskpor pala Indonesia ke Vietnam. Dan apabila variabel lain dianggap tetap atau tidak berubah, maka apabila terjadi kenaikan gross domestic product Vietnam sebesar 1 milliar US\$ akan menyebabkan volume eskpor pala Indonesia ke Vietnam meningkat sebesar 0,033625 ton. gross domestic product adalah indikator ekonomi untuk mengukur total nilai produk barang dan jasa akhir dalam suatu perekonomian. Gross domestic product adalah variabel yang menggambarkan keadaan perekonomian suatu negara. Apabila gross domestic product suatu negara semakin besar berarti menunjukkan keadaan perekonomian suatu negara tersebut semakin baik karena pendapatan negara tersebut yang semakin meningkat. Oleh karena itu apabila terjadi peningkatan gross domestic product negara Vietnam, maka akan semakin meningkatnya kemampuan negara Vietnam dalam kegiatan perdagangan internasional, dan akhirnya berdampak pada meningkatnya permintaan pala Indonesia ke Vietnam. Hal ini juga sesuai dengan penelitian yang dilakukan oleh Pratiwi (2015) dengan judul "Analisis Faktor Yang Mempengaruhi Ekspor Kakao Indonesia ke Malaysia dan Singapura" yang beranggapan bahwa gross domestic product negara importir berpengaruh positif terhadap volume eskpor indonesia.

\section{KESIMPULAN DAN SARAN}

\section{Kesimpulan}

Perkembangan ekspor pala Indonesia ke Vietnam periode tahun 1980 - 2017 dari sisi nilai tukar, harga internasional dan gross domestic product Vietnam rata-rata mengalami fluktuasi. Untuk volume ekspor berfluktuasi dan cenderung meningkat, untuk nilai tukar berfluktuasi cenderung terjadi depresiasi rupiah terhadap US\$, harga internasional berfluktuasi dan cenderung meningkat, terakhir gross domestic product Vietnam yang mengalami fluktuasi dan cenderung meningkat. Hasil analisis regresi linier berganda menunjukkan bahwa variabel nilai tukar, harga internasional, dan gross 
domestic product Vietnam berpengaruh signifikan terhadap variabel volume ekspor pala Indonesia ke Vietnam periode tahun 1980 - 2017.

\section{Saran}

Pemerintah melalui instansi terkait diharapkan dapat mengontrol nilai tukar terutama mengawal penguatan rupiah sehingga apresiasi nilai tukar rupiah tidak terlalu tinggi agar ekspor pala Indonesia meningkat, tetapi tidak terjadi depresiasi secara berkepanjangan yang berakibat pada terganggunya perekonomian Indonesia. dan pemerintah harus dapat meningkatkan kerjasama perdagangan bilateral antara Indonesia dan Vietnam untuk meningkatkan ekspor Indonesia.

\section{DAFTAR PUSTAKA}

Arham, I. (2009). Potensi strategis pertanian dalam membangun perekonomian Indonesia. dalam http://agromersindonesia.blogspot.com. diakses Tanggal: 22 Agustus 2019, pukul 02 : 00 WIB.

Asrori,K; Haryadi,H; \& Heriberta,H. (2015). Daya saing dan determinan permintaan ekspor minyak sawit Indonesia ke China, e-Jurnal Perspektif Ekonomi dan Pembangunan Daerah, 4 (1)

Badan Pusat Statistik. (2018). Data ekspor non migas dan migas Indonesia. dalam https://www.bps.go.id/. diakses Tanggal: 12 September 2019, pukul 03 : 00 WIB.

Dewi, P., Kusuma \& Dewi, Ayu., Suresmiathi. (2015). Pengaruh jumlah produksi, kusr dollar Amerika Serikat dan luas areal lahan terhadap ekspor karet Indonesia Tahun 1993-2013. E-Jurnal EP Unud, 4 (2) :80 - 89.

Ghozali, Imam. (2011). Aplikasi analisis multivariate dengan program SPSS. Badan Penerbit Universitas Diponegoro: Semarang.

Lind, dkk. (2008). Statistical technique in bussiness and Economic with Gobal Data Sets, Edition $13^{\mathrm{TH}}$. Salemba Empat: Jakarta.

Mejaya, A., Saleh., Fanani, Dahlan., \& Mawardi, M., Kholid. (2016). Pengaruh produksi, harga Internasional, dan Nilai Tukar Terhadap Volume Ekspor. Jurnal Administrasi Bisnis (JAB). 35 (2):20-29.

Pratiwi, Apriana. (2016). Analisis faktor yang mempengaruhi ekspor Kakao Indonesia ke Malaysia dan Singapura. Skripsi Fakultas Ekonomi Universitas Sriwijaya: Palembang.

Purnamawati, Astuti., dan Sri Fatmawati. (2013). Dasar-dasar ekspor dan impor, teori, praktik, dan prosedur. Edisi I. UUP STIM YKPN: Yogyakarta.

Pusat Data dan Informasi pertanian. (2016). Negara eksportir pala di dunia. dalam http://epublikasi.setjen.pertanian.go.id/arsip-outlook/75-outlook-

perkebunan/419-outlook-pala-2016. diakses Tanggal 12 Juni 2019, pukul 19 : 00 WIB.

Rosmeli,R; \& Hastuti, D.(2019).Determinan produksi perkebunan karet di Desa Purwasari Kabupaten Bungo, Jurnal Paradigma Ekonomika, 14 (2), 66-76

Sartika,NR; Amril,A; \& Artis, D. (2018). Analisis determinan impor gula Indonesia dari Thailand, e-Jurnal Perdagangan Industri dan Moneter, 6 (1), 1-13

Soeratno. (2008). Metode penelitian untuk ekonomi dan bisnis. UPP STIM YKPN: Yogyakarta.

Tan, Syamsurijal. (2016). Ilmu ekonomi internasional (perdagangan internasional). Fakultas Ekonomi dan Bisnis UNJA: Jambi.

Wahyudi, S,T. (2016). Konsep dan penerapan ekonometrika menggunakan E-Views. PT Grafindo Persada: Jakarta. 